\title{
Thyroxine Increases Submandibular Gland Nerve Growth Factor and Epidermal Growth Factor Concentrations Precociously in Neonatal Mice: Evidence for Thyroid Hormone-Mediated Growth Factor Synthesis
}

\author{
PETER WALKER ${ }^{1}$ \\ Unite de Bioregulation Cellulaire, Service d'Endocrinologie, Le Centre hospitalier de l'Universite Laval, \\ Sainte-Foy, Quebec, Canada
}

\begin{abstract}
Thyroxine $\left(T_{4}\right)$ administration to adult female mice significantly increases submandibular gland (SMG) nerve growth factor (NGF) and epidermal growth factor (EGF) concentrations and does so in a time- and dose-dependent manner. Postnatal maturation of the SMG can be markedly accelerated by $\mathrm{T}_{4}$ treatment. We, therefore, performed a series of experiments to examine the effect of $T_{4}$ on SMG NGF and EGF content and concentration as a function of postnatal age in neonatal mice. In experiment 1 , male and female neonatal Swiss-Webster mice received daily subcutaneous injections of $\mathrm{T}_{\mathbf{4}}(0.4 \mu \mathrm{g} /$ $\mathrm{g}$ body weight) for 6,13 , or 20 days and were sacrificed 24 $h$ after the last injection. Vehicle injected mice served as controls. SMG NGF and EGF content and concentration were measured by specific double antibody radioimmunoassay systems. Pools were made using either female or male SMGs. Since no significant differences were noted for NGF or EGF content using sex of the animal as the determining variable, the values were combined. At 7 days of age, mean SMG NGF and EGF content and concentration of control mice significantly exceeded those of $\mathrm{T}_{\mathbf{4}}$ treated animals $(p<0.05)$. At 14 days of age, mean SMG NGF and EGF content in $T_{4}$-treated mice significantly exceeded those in control mice by 39- and 22-fold, respec-
\end{abstract} tively $(p<0.001)$. At 21 days of age, these increases were 4100 - and 2400 -fold, respectively. In order to determine more precisely the time of onset of responsivity of the SMG to thyroid hormones, a second series of experiments was performed. Vehicle and $T_{4}(0.4 \mu \mathrm{g} / \mathrm{g}$ body weight daily) injected mice were sacrificed at $7,9,11$, and 14 days of age. SMG EGF concentration was measured by radioimmunoassay. $T_{4}$ treatment was without significant effect at 7 and 9 days of age. At 11 days of age, mean SMG EGF content and concentration in the $\mathrm{T}_{4}$-treated mice exceeded that in control mice by a factor of $2(p<0.05)$. Subsequently, SMG EGF content and concentration increased exponentially. Daily treatment of neonatal mice from birth or from the 7 th postnatal day resulted in similar SMG EGF content and concentration when measured at 14 days of age. These data indicate that $T_{4}$ administration to neo-

Received July 2, 1985; accepted November 18, 1985.

Correspondence: Peter Walker, M.D., F.R.C.P.(C), Division of Endocrinology and Metabolism, Ottawa Civic Hospital, 1053 Carling Avenue, Ottawa, Ontario K1Y 4E9, Canada.

Supported in part by Grant MA-6204 from the Medical Research Council of Canada.

${ }^{1}$ Scholar of the Fonds de la Recherche en Sante du Quebec. natal mice significantly increases SMG NGF and EGF concentrations and markedly accelerates their appearance in the gland as early as 11 days of age. Onset of SMG EGF responsiveness to thyroid hormone appears to commence at some time on or after the 7 th postnatal day. The observation of exponential increases in SMG growth factor concentrations strongly suggest thyroid hormone mediated synthesis. The use of the neonatal SMG as a model will allow further insights into the biosynthesis of NGF and EGF and also into the mechanism of thyroid hormone action. (Pediatr Res 20: 281-284, 1986)

\section{Abbreviations}

EGF, epidermal growth factor

NGF, nerve growth factor

SMG, submandibular gland

$\mathrm{T}_{3}$, triiodothyronine

$T_{4}$, thyroxine

The SMG of the adult mouse of both sexes contains high concentrations of NGF (1) and EGF (2). Levels in males exceed those in females by two orders of magnitude, reflecting the known sexual dimorphism of the SMG. NGF and EGF concentrations can be significantly modulated by androgens $(3,4)$ and thyroid hormones (5-7) in the adult animal. In the neonatal mouse, the SMG is histologically and biochemically immature and contains very low concentrations of NGF and EGF (8). Thyroxine administration to neonatal mice accelerates histological and biochemical maturation of the SMG $(7,9-12)$. Aloe and Levi-Montalcini (13), and Gresik and Barka (9) have shown that thyroxine treatment of immature mice results in the appearance of measurable NGF and EGF, respectively, in the SMG as early as 15 days of age. In previous studies, we have shown that in normal intact neonatal mice, SMG NGF and EGF concentrations increase exponentially after 17-18 days of age (8) in agreement with previous reports $(13,14)$, and the increases appear to correlate with increasing concentrations of $T_{4}$ and $T_{3}(8)$. Since the time course of action of triiodothyronine requires a lag time of approximately $40 \mathrm{~h}$ prior to the appearance of newly accumulated EGF in the SMG of adult intact female mice (15), it became of interest to examine the effect of thyroxine on SMG NGF and EGF concentrations and the time of onset of thyroid hormone action in the neonatal mouse. 


\section{MATERIALS AND METHODS}

Female Swiss-Webster mice were mated at the supply house (Simonsen Laboratories, Gilroy, CA) and were shipped to the CHUL vivarium on the 12 th day of pregnancy. Pregnant mice were housed in individual plastic cages on a bedding of wood shavings in a temperature- $\left(22 \pm 1^{\circ} \mathrm{C}\right)$ and light- (14 h light) controlled room with free access to laboratory food and water. Humidity was not controlled.

At birth, the litters were reduced to 10 pups per dam. Male and female pups were distributed randomly within and across litters. Litters were then randomly chosen for $T_{4}$ or for vehicle injection. Pups received daily subcutaneous injections of $0.4 \mu \mathrm{g}$ $\mathrm{T}_{4} / \mathrm{g}$ body weight in $0.005 \mathrm{~N} \mathrm{NaOH}, 0.9 \% \mathrm{NaCl}$; control mice received equivalent volumes of vehicle alone. Pups were sacrificed $24 \mathrm{~h}$ after the last $\mathrm{T}_{4}$ injection at 7,14 , and 21 days of age in experiment 1 , and at $7,9,11$, and 14 days of age in experiment 2. In a third experiment, neonatal mice were injected daily with $\mathrm{T}_{4}(0.4 \mu \mathrm{g} / \mathrm{g}$ body weight) from birth through 13 days or from the 7 th through the 13 th postnatal day and were sacrificed on the 14 th postnatal day, $24 \mathrm{~h}$ after the last injection. In order to yield sufficient material, SMGs were pooled for analysis. Pups were pooled according to sex and were pooled randomly across litters in order to avoid maternal influences. Pools comprised six animals each at all ages except for 21-day-old mice when SMGs from three mice were pooled. SMGs were removed on ice and were homogenized in $10 \mathrm{vol} 0.05 \mathrm{M}$ phosphate buffered saline, $\mathrm{pH} 7.2$ at $4^{\circ} \mathrm{C}$. The supernatant was recovered after centrifugation at $25,000 \times g$ for $30 \mathrm{~min}$ at $4^{\circ} \mathrm{C}$ and was frozen at $-20^{\circ} \mathrm{C}$ pending radioimmunoassay.

SMG NGF and EGF concentrations were measured by sensitive and specific radioimmunoassays $(5,6)$. The samples were measured in duplicate and at two dilutions within the same assay run. Supernatant protein concentrations were measured by the method of Lowry et al. (16) using bovine serum albumin as standard.

Statistical analyses were performed using Student's $t$ test for unpaired observations.

\section{RESULTS}

Experiment 1. Body weights of $\mathrm{T}_{4}$-treated neonatal mice were consistently lower than those of vehicle injected mice (data not shown). SMG weights did not differ significantly between the vehicle and $\mathrm{T}_{4}$ injected mice at 7 or 14 days of age. At 21 days of age, there was a significant increase in SMG weight in $T_{4^{-}}$ treated mice compared to controls $(p<0.001)$.

Since no significant sex differences were noted for NGF and EGF concentrations at 7, 14, and 21 days of age in both control and $\mathrm{T}_{4}$-treated mice, the results were combined (Table 1). In control mice, SMG NGF and EGF contents and concentrations declined at 14 days of age $(p<0.05)$ and subsequently increased to levels similar to those observed at 7 days, at 21 days of age. SMG NGF and EGF content remained stable through 14 days and increased significantly between 14 and 21 days of age. $\mathrm{T}_{4}$ treatment resulted in a significant decrease in SMG NGF and EGF content and concentration at 7 days of age compared to vehicle injected control mice $(p<0.05)$. Subsequently, SMG NGF and EGF concentrations in $\mathrm{T}_{4}$-treated mice increased significantly and exceeded those measured in controls. The increases were exponential; at 14 days of age, the mean fold increases for SMG NGF and EGF concentrations were 31 and 23 , respectively, those of control mice; at 21 days of age, 2100 and 1500-fold increases, respectively, were noted. The fold increases in NGF and EGF content at 14 days of age were 39 and 22 , respectively, increasing further to 4100 and 2400 , respectively, at 21 days of age.

Experiment 2. The results of experiment 1 indicated that the neonatal SMG begins to respond to thyroid hormones during the 2 nd postnatal wk. In order to determine the time of onset of responsiveness of the gland to $T_{4}$, vehicle and $T_{4}(0.4 \mu \mathrm{g} / \mathrm{g}$ body weight daily) injected mice were sacrificed at $7,9,11$, and 14 days of age. Body weights of $\mathrm{T}_{4}$-injected mice were generally, but not significantly, lower than those of control mice (data not shown). As observed in experiment 1 , there was no significant hypertrophic effect of $\mathrm{T}_{4}$ on SMG weight between 7 and 14 days of age.

$\mathrm{T}_{4}$ administration had no significant effect on SMG EGF content or concentration at 7 or 9 days of age (Table 2). At 11 days of age, mean SMG EGF content and concentration in the $\mathrm{T}_{4}$-treated mice exceeded that in the control mice by a factor of $2(p<0.05)$. Subsequently, as in experiment 1 , the increase in SMG EGF concentration was exponential.

Experiment 3. Mean body weight of 14-day-old mice treated with $T_{4}$ daily from the 7 th to the 13 th postnatal day was slightly but significantly greater than that of mice treated with $\mathrm{T}_{4}$ daily from birth through 13 days of age ( $p<0.05$; data not shown).

Table 2. Effect of $T_{4}$ administration on $S M G$ EGF content and concentration during early neonatal life

\begin{tabular}{cccc}
\hline & & \multicolumn{2}{c}{ EGF } \\
\cline { 3 - 4 } $\begin{array}{c}\text { Age } \\
\text { days) }\end{array}$ & $\mathrm{T}_{4}$ & $\mathrm{ng} / \mathrm{gland}$ & $\mathrm{ng} / \mathrm{mg}$ protein \\
\hline 7 & - & $0.095 \pm 0.002$ & $0.092 \pm 0.005$ \\
& + & $0.078 \pm 0.003$ & $0.084 \pm 0.007$ \\
& & & \\
9 & - & $0.102 \pm 0.017$ & $0.099 \pm 0.007$ \\
& + & $0.110 \pm 0.011$ & $0.079 \pm 0.006$ \\
& & & \\
11 & - & $0.080 \pm 0.007$ & $0.061 \pm 0.002$ \\
& + & $0.150 \pm 0.019^{*}$ & $0.120 \pm 0.017^{*}$ \\
& & & \\
14 & - & $0.132 \pm 0.005$ & $0.057 \pm 0.002$ \\
& + & $55.30 \pm 9.50 \dagger$ & $24.80 \pm 3.09 \dagger$ \\
\hline
\end{tabular}

$* p<0.05$.

$\dagger p<0.001$.

Table 1. Effect of $T_{4}$ administration on $S M G N G F$ and EGF content and concentration in neonatal mice

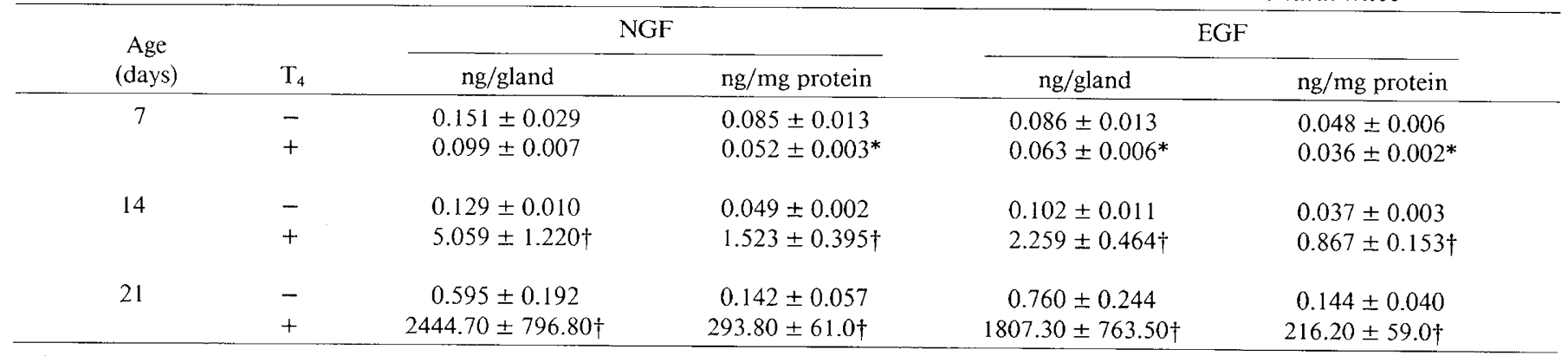

\footnotetext{
$* p<0.05$.
}

$\dagger p<0.001$. 
Table 3. Effect of $T_{4}$ administration from birth to 13 days or from 7 to 13 days of age on SMG EGF content and concentration at 14 days of age

\begin{tabular}{|c|c|c|c|}
\hline \multirow{2}{*}{\multicolumn{2}{|c|}{ Group }} & \multicolumn{2}{|c|}{ EGF } \\
\hline & & \multirow{2}{*}{$\begin{array}{c}\mathrm{ng} / \mathrm{gland} \\
19.1 \pm 2.2\end{array}$} & \multirow{2}{*}{$\frac{\mathrm{ng} / \mathrm{mg} \text { protein }}{5.6 \pm 0.5}$} \\
\hline$T_{4}$ & $0-13$ & & \\
\hline $\mathrm{T}_{4}$ & $7-13$ & $21.6 \pm 3.0$ & $5.7 \pm 0.8$ \\
\hline
\end{tabular}

No significant differences were noted, however, for mean SMG weight or mean SMG EGF concentration or content (Table 3).

\section{DISCUSSION}

The SMG of the neonatal mouse is immature histologically and biochemically. At birth, the granular tubule cells, the site of NGF and EGF synthesis $(17,18)$, are absent but begin to make their appearance toward the end of the 2nd postnatal wk (19). The factors responsible for histological and biochemical maturation of the SMG are unknown. In the adult mouse, granular tubule cells are more developed in male mice than in females, and in immature mice a clear sexual dimorphism in the histological appearance of the gland is evident by 20 days of age (19). These sexual differences in adult mice, and presumably in immature mice, are androgen dependent $(3,4,19)$.

Recently, attention has focused on the potential role of thyroid hormones as modulators of SMG maturation. Thyroxine has both hyperplastic and hypertrophic effects on the adult SMG (20); the changes are most marked in the granular tubule cells. $\mathrm{T}_{4}$ administration to adult mice significantly increases $\mathrm{SMG}$ $\operatorname{NGF}(5,6,13), \operatorname{EGF}(6,7)$, and renin (21) concentrations. SMG protease activity also is increased by $\mathrm{T}_{4}$ administration (7). Further, the ontogenetic profiles of SMG NGF and EGF concentrations correlate temporally with those of serum $T_{4}$ and $T_{3}(8)$.

The present study confirms and extends previous observations on the time course of appearance of NGF and EGF in the SMG of neonatal mice in response to thyroid hormone administration. Aloe and Levi-Montalcini (13) showed that administration of $T_{4}$ to postnatal mice significantly increased SMG NGF concentration at 14 days of age when treatment was instituted at 7 days of age. Gresik and Barka (9) reported that thyroxine treatment from birth was associated with a marked increase in SMG EGF content at 15 days of age. In both cases, continued administration of $T_{4}$ led to further exponential increases in SMG NGF and EGF content. The present study indicates that concentrations of both NGF and EGF increase significantly in the SMG of $T_{4}$-treated neonatal mice by 14 days of age and that EGF increases significantly as early as 11 days of age. In both cases, the increases were exponential and the 2400-plus fold increases in SMG NGF and EGF contents between 14 and 21 days of age in the $\mathrm{T}_{4}$-treated mice strongly suggest thyroid hormone-mediated synthesis of both growth factors. The exponential increase in SMG NGF and EGF concentrations in $\mathrm{T}_{4}$-treated mice between 14 and 21 days of age, moreover, is reminiscent of the increase seen in normal animals after 21 days of age (8).

Kumegawa et al. $(10,22)$ have shown that $\mathrm{T}_{4}$ administration to neonatal mice increases precociously the number of secretory granules and the appearance of esteroprotease activity in the granular tubule cells. Unlike androgens, for which no response was noted prior to $15-21$ days postnatally $(12,23), T_{4}$ increases mitochondrial $\alpha$-glycerophosphate dehydrogenase activity, a known biochemical marker for thyroid hormone action (24), and glucose-6-phosphate dehydrogenase activity, a granular tubule cell marker $(12)$, by the 5 th postnatal day $(11,12)$. Protease activity, however, was not modified by $T_{4}$ treatment prior to 15 days postnatally (12). In the present study, a clear response was noted for EGF as early as 11 days of age.
Responsiveness of the SMG to thyroid hormone administration implies the presence of specific nuclear $T_{3}$ receptors in the SMG. Although $T_{3}$ receptors have not, as yet, been demonstrated in the neonatal SMG, they have been shown in the adult gland (15). The $\alpha$-glycerophosphate dehydrogenase and glucose-6phosphate dehydrogenase responses of the SMG at 5 days of age, before the appearance of the NGF, EGF, or protease responses, imply the presence of $T_{3}$ receptors in the gland prior to the appearance of mature granular tubule cells. The failure of the gland to respond to $T_{4}$ administration in terms of NGF or EGF accumulation suggests postreceptor immaturity of intracellular biosynthetic mechanisms in the granular tubule cells of newborn mice. This sequence of events would be compatible with initial thyroid hormone responsiveness being localized to granular tubule cell precursor during early neonatal life and thyroxine accelerated appearance of mature granular tubule cells and their biosynthetic products. After completion of these studies, Lakshmanan et al. (25) reported that $T_{4}$ treatment during the first postnatal week increased SMG RNA, protein, and lipid contents but had no significant effects on SMG NGF concentration.

Studies in adult female mice indicate that following administration of a saturating dose of $\mathrm{T}_{3}$, SMG EGF concentration remains unchanged for approximately $40 \mathrm{~h}$ before increasing to maximum levels $96 \mathrm{~h}$ after $T_{3}$ injection (15). If the neonatal granular tubule cell, once having begun to mature histologically, behaves as does the adult, the present data suggest that the granular tubule cells may begin to respond to $T_{4}$ exposure as early as 7-8 days of age. The results of experiment 3 indicate that SMG EGF concentration measured at 14 days of age in mice which had received daily $T_{4}$ injections from 7 days of age was not statistically different from that of mice injected from birth. This observation is compatible with the hypothesis that SMG EGF responsiveness to thyroid hormones occurs at some point on or after the 7th postnatal day. Moreover, the results suggest that exposure to thyroid hormones prior to 7 days of age is not necessary for induction of accelerated maturation of the SMG using EGF or NGF as the end-point determinant of such maturation. These results, however, differ slightly from those reported by Lakshmanan et al. (25) who showed a significant increase in SMG EGF content in 15-day-old mice treated from birth compared to mice treated from day 7 . The differences are difficult to reconcile since Lakshmanan et al. (25) used essentially the same protocol employed in the present study.

A further point of interest pertains to the observation of significant, albeit low concentrations of both NGF and EGF in the neonatal mouse SMG and is in agreement with previous observations $(8,25)$, but not with those of other groups $(9,13$, 26). The reason for this discrepancy is not clear, particularly since the sensitivities of the assay systems are similar. Extensive cross-reactive studies for both NGF and EGF antisera used in these studies have failed to identify molecules which result in significant displacement of either radioligand. Nexø et al. (27) have reported by radioimmunoassay and by radioreceptor assay the presence of significant amounts of EGF in fetal mouse tissues. Discrepant results in the two systems suggested that the fetal EGF molecule, while retaining its ability to bind to placental membrane receptors, was immunologically different from adult SMG EGF. It is possible, therefore, that the anti-EGF antiserum used in these studies may recognize the putative fetal EGF. A similar argument can be advanced for NGF. However, evidence in favor of a fetal NGF is lacking. An additional possibility is that SMG EGF may reflect EGF derived from maternal milk (28). Of interest is the observation that $T_{4}$ administration to neonatal mice significantly decreases SMG NGF and EGF content at 7 days of age, suggesting that thyroid hormones accelerate disappearance and/or catabolism of the growth factors from the gland in the early postnatal period. Whether this reflects catabolism of glandular or circulating NGF and EGF is not known.

In sum, the present observations demonstrate clearly that $T_{4}$ administration to neonatal mice exponentially increases SMG 
NGF and EGF concentrations in a manner compatible with $\mathrm{T}_{4^{-}}$ induced synthesis of the growth factors. The use of the neonatal mouse SMG will allow further insight into the mechanism of thyroid hormone action.

\section{REFERENCES}

1. Green LA, Shooter EM 1980 The nerve growth factor: biochemistry, synthesis and mechanism of action. Ann Rev Neurosci 3:353-402

2. Carpenter G, Cohen S 1979 Epidermal growth factor. Ann Rev Biochem 48:193-216

3. Byyny RL, Orth DN, Cohen S, Doyne ES 1974 Epidermal growth factor: effect of androgens and adrenergic agents. Endocrinology 95:776-782

4. Ishii DN, Shooter EM 1975 Regulation of nerve growth factor synthesis in mouse submaxillary gland by testosterone. J Neurochem 25:843-851

5. Walker P, Weichsel ME Jr, Guo SM, Fisher DA, Fisher DA 1980 Radioimmunoassay for mouse nerve growth factor (NGF). Effects of thyroxine administration on tissue NGF levels. Brain Res 186:331-341

6. Walker P, Weichsel ME Jr, Hoath SB, Poland RE, Fisher DA 1981 Effects of thyroxine, testosterone and corticosterone on nerve growth factor (NGF) and epidermal growth factor (EGF) concentrations in female mouse submaxillary gland. Dissociation of NGF and EGF responses. Endocrinology 109:582-587

7. Gresik EW, Schenkein I, Van Der Noen H, Barka T 1981 Hormonal regulation of epidermal growth factor and protease in the submandibular gland of the adult mouse. Endocrinology 109:924-929

8. Walker P, Weichsel ME Jr, Eveleth D, Fisher DA 1982 Ontogenesis of nerve growth factor and epidermal growth factor in submaxillary glands and nerve growth factor in brains of immature male mice: correlation with ontogenesis of serum levels of thyroid hormones. Pediatr Res 16:520-524

9. Gresik EW, Barka T 1980 Precocious development of granular convoluted tubules in the mouse submaxillary gland induced by thyroxine or by thyroxine and testosterone. Am J Anat 159:177-185

10. Kumegawa M, Takuma T, Takagi Y 1977 Precocious induction of secretory granules by hormones in convoluted tubules of mouse submandibular glands. Am J Anat 149:111-114

11. Tajima Y, Utsumi N, Takuma T, Kumegawa M 1979 Histochemical study on the localization of glucose-6-phosphate dehydrogenase induced by androgen or thyroxine in the convoluted tubules of mouse submandibular gland. Histochemistry 63:261-264

12. Takuma T, Hosoda S, Tanemura T, Kumegawa M 1981 Development of responsiveness of mouse submandibular gland to androgen and thyroid hormone. J Dent Res 60:77-79
13. Aloe L, Levi-Montalcini 1980 Comparative studies on testosterone and Lthyroxine effects on the synthesis of nerve growth factor in mouse submaxillary salivary glands. Exp Cell Res 125:15-22

14. Byyny RL, Orth DN, Cohen S 1972 Radioimmunoassay of epidermal growth factor. Endocrinology 90:1261-1266

15. Walker P, Coulombe P, Dussault JH 1984 Time- and dose-dependent effect of triiodothyronine on submaxillary gland epidermal growth factor concentration in aduit female mice. Endocrinology 111:1133-1139

16. Lowry OH, Rosebrough NJ, Farr AL, Randall RJ 1951 Protein measurement with the Folin phenol reagent. J Biol Chem 193:265-275

17. Schwab M, Stockel K, Thoenen H 1976 Immunocytochemical localization of nerve growth factor (NGF) in the submandibular gland of adult mice by light and electron microscopy. Cell Tissue Res 169:289-299

18. Gresik EW, Barka T 1977 Immunocytochemical localization of epidermal growth factor in mouse submandibular gland. J Histochem Cytochem 25:1027-1035

19. Gresik EW, MacRae E 1975 The postnatal development of the sexually dimorphic duct system and of amylase activity in the submandibular glands of mice. Cell Tissue Res 157:411-422

20. Gresik EW, Van Der Noen H, Barka T 1981 Hypertrophic and hyperplastic effects of thyroxine on the submandibular gland of the mouse. Anat Res 200:443-446

21. Wilson CM, Myhre JJ, Reynolds RC, Wilson JD 1982 Regulation of mouse submaxillary gland renin by thyroxine. Endocrinology 110:982-989

22. Takuma T, Tanemura T, Hosoda S, Kumegawa M 1978 Effects of thyroxine and 5- $\alpha$-dihydroxy-testosterone on the activities of various enzymes in the mouse submandibular gland. Biochem Biophys Acta 541:143-149

23. Dunn JF, Wilson JD 1975 Developmental study of androgen responsiveness in submandibular gland of the mouse. Endocrinology 96:1671-1678

24. Lee YP, Lardy HA 1965 Influence of thyroid hormones on $L$ - $\alpha$-glycerophosphase dehydrogenase and other dehydrogenase in various organs of the rat. J Biol Chem 240:1427-1436

25. Lakshmanan J, Beri U, Perheenturpa J, Grueters A, Kim H, Macaso T, Fisher DA 1984 Acquisition of submandibular gland nerve growth factor (SMG$\mathrm{NGF}$ ) responsiveness to thyroxine administration in neonatal mice. J Neurosci Res 12:71-85

26. Gresik EW, Barka T 1978 Immunocytochemical localization of epidermal growth factor during the postnatal development of the submandibular gland of the mouse. Amer J Anat 151:1-10

27. Nexø E, Hollenberg MD, Figueroa A, Pratt RM 1980 Detection of epidermal growth factor-urogastrone and its receptor during fetal mouse development. Proc Natl Acad Sci USA 77:2782-2785

28. Gresik EW, Van Der Noen, Barka T 1984 Transport of ${ }^{125}$ I-EGF into milk and effect of siloadenectomy on milk EGF in mice. Am J Physiol 247:E349E354 